\title{
Pengaruh Kompetensi terhadap Kinerja Pegawai pada Biro Pemerintahan dan Kerjasama Sekretariat Daerah Provinsi Jawa Barat
}

\section{The Effect of Competence on Performance Employees in Biro Pemerintahan dan Kerjasama Sekretariat Daerah Provinsi Jawa Barat}

\author{
Akhmad Fauzi \\ Program Pasca Sarjana Universitas Pasundan \\ JI. Sumatera No.41, Babakan Ciamis, Kec. Sumur Bandung, Kota Bandung, Jawa \\ Barat 40117 \\ *corresponding author E-mail: adjie80@gmail.com
}

Diterima: 10 Juni 2019; Direvisi: 6 Juli 2019; Disetujui: 15 Juli 2019

\begin{abstract}
ABSTRAK
Penelitian ini dilatarbelakangi oleh adanya fenomena yang terjadi pada Biro Pemerintahan dan Kerjasama Sekretariat Daerah Provinsi Jawa Barat saat ini yaitu indikasi belum optimalnya kinerja pegawai. Hal ini ditengarai sebagai akibat dari belum optimalnya kompetensi pegawai. Metode yang digunakan dalam penelitian ini adalah Explanatory survey. Metode ini tidak hanya menjelaskan atau menggambarkan fakta empiris yang ditemui di lapangan tetapi juga akan menjelaskan analisis pengaruh, baik secara parsial maupun simultan dalam hal ini pengaruh Kompetensi Pegawai terhadap kinerja pegawai. Jumlah sampel yang diteliti adalah sebanyak 42 orang responden. Analisis data dan pengujian hipotesis dalam penelitian ini dilakukan dengan menggunakan pengujian path analysis. Hasil penelitian ini menunjukkan bahwa secara simultan kompetensi pegawai berpengaruh positif dan signifikan terhadap kinerja pegawai pada Biro Pemerintahan dan Kerjasama Sekretariat Daerah Provinsi Jawa Barat dengan kontribusi sebesar 60,4\%, sedangkan sisanya sebesar 39,4\% dipengaruhi oleh variabel lain yang tidak diteliti.
\end{abstract}

Kata kunci: Kompetensi, Kinerja, Jawa Barat

\section{ABSTRACT}

This research is motivated by the existence of a phenomenon that occurs in the Bureau of Government and Cooperation of the Regional Secretariat of West Java Province, which is an indication of the lack of optimal performance of employees. This is suspected to be a result of the lack of optimal employee competency. The method used in this study is Explanatory survey. This method does not only explain or describe empirical facts found in the field, but will also explain the effect analysis, both partially and simultaneously in this case the influence of 
Employee Competence on employee performance. The number of samples studied were 42 respondents. Data analysis and hypothesis testing in this study were carried out using path analysis testing. The results of this study indicate that simultaneously employee competency has a positive and significant effect on the performance of employees in the Government Bureau and Cooperation of the Regional Secretariat of West Java Province with a contribution of 60.4\%, while the remaining $39.4 \%$ is influenced by other variables not examined. Keywords: Competence, Performance, Jawa Barat

\section{PENDAHULUAN}

Mewujudkan kepemerintahan yang baik (good governance), reformasi birokrasi dalam tubuh pemerintah daerah merupakan suatu kebutuhan. Reformasi birokrasi diarahkan untuk terciptanya organisasi yang efisien, efektif, rasional dan proporsional sesuai dengan kebutuhan dan kemampuan daerah, adanya koordinasi, integrasi, sinkronisasi, simplifikasi serta komunikasi kelembagaan antara pusat dan daerah, mengidentifikasi permasalahan dan hambatan kinerja, maka perlu di dukung oleh kompetensi pegawai yang sesuai dengan tuntutan lingkungan dewasa ini. Tuntutan lingkungan tersebut, adalah organisasi yang dapat memenuhi dan memberikan kepuasan kepada masyarakat atau pelanggan yang antara lain berupa pemberian pelayanan yang tertib, mudah dan cepat.

Berlakunya Undang-Undang Nomor 23 Tahun 2014 tentang Pemerintahan telah memberikan perubahan yang signifikan terhadap jalannya pemerintahan di daerah. Oleh karena itu, paradigma pemerintahan ini bersifat desentralistik, sehinga diharapkan pembangunan yang dilaksanakan tumbuh dan berkembang dari masyarakat, sehingga hasil-hasil pembangunan dapat dinikmati oleh masyarakat secara keseluruhan. Terjadinya berbagai perubahan paradigma pemerintahan, merupakan hal yang harus dilakukan dalam rangka adaptasi terhadap kecenderungan berbagai tuntutan, terutama tuntutan pelayanan publik kepada pemerintah. Oleh karena itu upaya mewujudkan suatu lembaga atau instansi pemerintah yang berkualitas merupakan langkah yang strategis guna mengantisipasinya. Berkenaan dengan hal tersebut, diperlukan dukungan kemampuan berbagai sumberdaya, khususnya sumberdaya manusia aparatur pemerintah yang baik, 
POLITICON : Jurnal Ilmu Politik Vol.1 No.1; Hal 88 - 103

Website : http://journal.uinsgd.ac.id/index.php/politicon

ISSN : 2685-6670 ( Online )

sehingga pelaksanaan tugas dapat dicapai secara berdayaguna dan berhasil guna.

Biro Pemerintahan dan Kerja Sama Sekretariat Daerah Provinsi Jawa Barat merupakan salah satu unit kerja pada Sekretariat Daerah Provinsi Jawa Barat yang mempunyai tugas pokok menyelenggarakan perumusan kebijakan umum, pengkoordinasian administratif terhadap pelaksanaan tugas perangkat daerah serta pelayanan administratif aspek pemerintahan dan kerjasama, meliputi urusan pemerintahan daerah, tata pemerintahan dan kerjasama yang menjadi kewenangan Provinsi, menyelenggarakan tugas dekonsentrasi sampai dengan dibentuk Sekretariat Gubernur sebagai Wakil Pemerintah Pusat serta melaksanakan tugas pembantuan sesuai bidang tugasnya.

Biro Pemerintahan dan Kerjasama Sekretariat Daerah Provinsi Jawa Barat mempunyai fungsi-fungsi sebagai berikut:

1. Penyelenggaraan perumusan kebijakan umum serta koordinasi, administratif, supervisi, pembinaan, pengendalian dan pelayanan administratif dalam aspek pemerintahan dan kerja sama

2. Penyelenggaraan administrasi Biro

3. Penyelenggaraan evaluasi dan pelaporan pelaksanaan tugas Biro

4. Penyelenggaraan fungsi lain sesuai dengan tugas pokok dan fungsinya

Biro Pemerintahan dan Kerjasama Sekretariat Daerah Provinsi Jawa Barat, terus berupaya untuk meningkatkan kompetensi pegawai guna mewujudkan tujuan organisasi melalui visi maupun misi secara komprehensif, efektif dan efisien. Namun demikian sumber daya yang ada menjadi kendala di dalam pelaksanaan tugas pokok dan fungsi tersebut, salah satunya adalah kompetensi pegawai yang masih rendah sehingga mempengaruhi kinerja pegawai.

Menurut Mulyasa (2008:26), kompetensi diartikan dan dimaknai sebagai perangkat perilaku efektif yang terkait dengan eksplorasi dan investigasi, menganalisis dan memikirkan, serta memberikan perhatian dan 
mempersepsi yang mengarah pada seseorang menemukan cara-cara untuk mencapai tujuan tertentu secara efektif dan efisien.

Berdasarkan pendapat tersebut di atas, maka pegawai yang mempunyai kompetensi dapat mengembangkan prestasinya sesuai dengan harapan yang telah ditetapkan organisasi. Pegawai yang memiliki kompetensi yang mumpuni akan berpengaruh terhadap kinerja pegawai dalam organisasi.

Menurut Mangkunegara (2005:67), berpendapat bahwa kinerja adalah hasil kerja secara kualitas dan kuantitas yang dicapai oleh seorang pegawai dalam melaksanakan tugasnya sesuai dengan tanggung jawab yang diberikan kepadanya. Kinerja pegawai yang dimaksud adalah kemampuan pegawai di dalam melaksanakan tugas-tugas pekerjaan agar hasil kerja yang dicapai sesuai dengan sasaran dan wewenang serta tanggungjawab yang dibebankan kepadanya sesuai dengan aturan dan pedoman kerja yang telah disepakatinya.

Berdasarkan hasil pengamatan awal di Biro Pemerintahan dan Kerjasama Sekretariat Daerah Provinsi Jawa Barat, kinerja pegawai masih rendah. Hal ini terlihat dari adanya aspek-aspek efektivitas kerja sebagai berikut:

1. Kualitas kerja pegawai masih rendah. Contohnya pada Bagian Tata Pemerintahan dalam membuat laporan fasilitasi dan evaluasi terkadang belum sesuai dengan format laporan yang telah disediakan sehingga harus diperbaiki sesuai dengan format yang telah ditetapkan.

2. Kuantitas kerja pegawai masih rendah. Contohnya pada Bagian Kerjasama dalam melaksanakan pekerjaan masih belum mencapai target yang telah ditetapkan. Jumlah target kerjasama antar daerah, kabupaten/kota, antar provinsi dan kerja sama luar negeri yang ditargetkan 60 dokumen hanya 9 dokumen yang terpenuhi.

3. Waktu penyelesaian pekerjaan yang diberikan kepada pegawai masih belum efektif. Contohnya pada Bagian Urusan Pemerintahan Daerah sering terlambat dalam melaporkan tugasnya. Berdasarkan ketentuan yang seharusnya tiap akhir bulan melaporkan hasil realisasi kegiatan, 
pada kenyataannya dilaporkan pada pertengahan bulan selanjutnya. Hal ini juga menyebabkan terlambatnya juga laporan kinerja bulanan.

Berdasarkan aspek-aspek kinerja tersebut di atas diduga disebabkan karena belum optimalnya kompetensi yang dimiliki oleh pegawai. Dilihat dari sudut pandang fokus penelitian bahwa kompetensi pegawai dikaitkan dengan kinerja pegawai merupakan salah satu fungsi dari administrasi publik, sedangkan dilihat dari lokus penelitian bahwa Biro Pemerintahan dan Kerjasama Sekretariat Daerah Provinsi Jawa Barat merupakan salah satu institusi publik yang mana berdasarkan ilmu administrasi publik objek yang diteliti mempunyai peran pelayanan kepada masyarakat (public service).

Berdasarkan permasalahan di atas maka peneliti tertarik untuk meneliti lebih jauh dan bermaksud mengadakan penelitian dengan judul: "Pengaruh Kompetensi Terhadap Kinerja Pegawai pada Biro Pemerintahan dan Kerjasama Sekretariat Daerah Provinsi Jawa Barat".

Berpijak dari latar belakang penelitian di atas, maka yang jadi pernyataan masalahnya (problem statement) adalah kinerja pegawai di Biro Pemerintahan dan Kerjasama Sekretariat Daerah Provinsi Jawa Barat masih rendah, hal ini diduga karena kompetensi pegawai yang masih belum optimal. Tujuan dilaksanakannya penelitian ini adalah sebagai berikut:

1. Untuk menganalisis besarnya pengaruh kompetensi terhadap kinerja pegawai pada Biro Pemerintahan dan Kerjasama Sekretariat Daerah Provinsi Jawa Barat.

2. Untuk menganalisis besarnya pengaruh kompetensi yang diukur melalui: pengetahuan (knowledge), keterampilan (skill), konsep diri (self concept), ciri diri (trait), dan motif (motive) terhadap kinerja pegawai di Biro Pemerintahan dan Kerjasama Sekretariat Daerah Provinsi Jawa Barat.

Menerapkan secara teoritis konsep kompetensi dalam memecahkan masalah kinerja pegawai di Biro Pemerintahan dan Kerjasama Sekretariat Daerah Provinsi Jawa Barat. 


\section{METODE PENELITIAN}

Objek penelitian ini adalah Biro Pemerintahan dan Kerjasama Sekretariat Daerah Provinsi Jawa Barat. Metode penelitian yang digunakan dalam penelitian ini adalah metode explanatory survey. Pemilihan metode ini didasarkan pada pertimbangan bahwa metode ini tidak hanya menjelaskan atau menggambarkan fakta empiris di lapangan tetapi juga akan menjelaskan analisis pengaruh.

Secara operasional penelitian ini meliputi dua variabel, terdiri dari variabel bebas yaitu kompetensi pegawai (X), sedangkan variabel terikatnya adalah kinerja pegawai (Y). Populasi yang akan dijadikan objek dalam penelitian ini adalah pegawai Biro Pemerintahan dan Kerjasama Sekretariat Daerah Provinsi Jawa Barat yang berjumlah 42 orang. Populasinya relatif kecil (kurang dari 100 orang), sehingga dilakukan penarikan sampel secara sensus (total sampling), sehingga jumlah sampel dalam penelitian ini sama dengan jumlah populasi penelitian yaitu 42 orang responden.

Adapun teknik pengumpulan data yang peneliti gunakan untuk menunjang metode deskriptif analisisdalam penelitian ini adalah:

1. Studi kepustakaan, yaitu suatu teknik dalam pengumpulan data dengan cara membaca, mempelajari buku literatur, referensi dan bahan bacaan lainnya yang berkaitan dengan masalah yang diteliti.

2. Studi lapangan, yaitu teknik memperoleh data dengan cara mengunjungi lokasi penelitian yang dilakukan dengan cara berikut:

a. Observasi, yaitu suatu cara pengumpulan data dengan teknik melibatkan diri ke dalam lokasi penelitian mengamati secara langsung mengenai kegiatan yang ada kaitannya dengan kompetensi pegawai dan kinerja pegawai pada Biro Pemerintahan dan Kerjasama Sekretariat Daerah Provinsi Jawa Barat.

b. Wawancara, yaitu teknik pengumpulan data dengan cara mengajukan tanya-jawab secara langsung kepada informan mengenai kegiatan yang ada kaitannya dengan kompetensi dan 
POLITICON : Jurnal Ilmu Politik Vol.1 No.1 ; Hal 88 - 103

Website : http://journal.uinsgd.ac.id/index.php/politicon

ISSN : 2685-6670 ( Online )

kinerja pegawai pada Biro Pemerintahan dan Kerjasama Sekretariat Daerah Provinsi Jawa Barat.

c. Angket, yaitu alat untuk mengumpulkan data dengan cara memberikan daftar pertanyaan tertulis yang disertai dengan alternatif jawaban yang telah disediakan kepada responden guna mendapatkan atau memperoleh keterangan atau pendapat dari responden, yaitu pegawai Biro Pemerintahan dan Kerjasama Sekretariat Daerah Provinsi Jawa Barat, sehubungan dengan kompetensi dan kinerja pegawai.

Teknik analisis data dalam penelitian ini menggunakan analisis jalur (path analysis) yaitu untuk melihat besarnya pengaruh baik secara parsial maupun secara simultan dari variabel kompetensi terhadap kinerja pegawai pada Biro Pemerintahan dan Kerjasama Sekretariat Daerah Provinsi Jawa Barat.

\section{TEMUAN DAN PEMBAHASAN}

\section{Sekilas Tentang Sekretariat Daerah Provinsi Jawa Barat}

Sejarah Singkat Sekretariat Daerah Provinsi Jawa Barat Berdasarkan undangundang Nomor 22 tahun 1999 pasal 60 Sekertariat Daerah merupakan salah satu unsur perangkat Daerah, yang pembentukannya berdasarkan Undang-undang Nomor 22 tahun 1999 pasal 68 ayat 1 dan peraturan pemerintah nomor 84 tahun 2000 pasal 1 ayat 2 yang kemudian dibentuk berdasarkan peraturan daerah nomor 13 tahun 2000 tentang sekertariat daerah. Berdasarkan Permendagri No. 13 Tahun 2006 Pasal 6 ayat (1) Sekretaris daerah merupakan koordinator pengelolaan keuangan daerah sebagaimana dimaksud dalam Pasal 5 ayat (3) huruf a berkaitan dengan peran dan fungsinya dalam membantu kepala daerah menyusun kebijakan dan mengkoordinasikan penyelenggaraan urusan pemerintahan daerah termasuk pengelolaan keuangan daerah. Tugas pokok sekretariat daerah yaitu membantu Gubernur dalam pelaksanaan tugas pemerintah, organisasi dan tatalaksana serta memberi pelayanan administratif kepada seluruh perangkat pemerintah. Dalam menyelenggarakan tugas pokoknya tersebut, Sekretariat 
Daerah juga berfungsi sebagai :

a. Pengkoordinasi perumusan kebijakan pemerintah daerah.

b. Penyelenggaraan Administrasi pemerintah dan pelaksanaan pelayanan admnistrasi kepada seluruh perangkat pemerintah daerah.

c. Pengendalian sumber daya aparatur, keuangan, prasarana dan sarana pemerintah daerah.

d. Pelaksana tugas lain yang diberikan oleh Gubernur dengan tugas dan fungsinya.

\section{Kompetensi Pegawai terhadap Efektifitas Kerja}

Kompetensi pegawai yang diharapkan berpengaruh secara signifikan terhadap efektivitas kerja pegawai dikarenakan apabila di dalam sebuah organisasi yang memiliki pegawai berkompeten baik maka akan berpengaruh kepada efektivitas kerja pegawai di dalam organisasi tersebut.

Spencer dalam Moeheriono (2009:3), berpendapat bahwa: “Kompetensi adalah karakteristik yang mendasari seseorang berkaitan dengan efektivitas kinerja individu dalam pekerjaannya atau karakteristik dasar individu yang memiliki hubungan kausal atau sebagai sebab-akibat dengan kriteria yang dijadikan acuan, efektif atau berkinerja prima atau superior di tempat kerja atau pada situasi tertentu".

Spencer dan Spencer dalam Hutapea dan Thoha (2008:28), mengungkapkan bahwa ada beberapa komponen utama pembentuk kompetensi, diantaranya adalah sebagai berikut:

1. Pengetahuan (knowledge), merupakan informasi yang dimiliki oleh seseorang. Pengetahuan adalah komponen utama kompetensi yang mudah diperoleh dan mudah diidentifikasi. Seseorang yang mengetahui tentang banyak hal belum tentu orang tersebut dapat melakukan apa yang diketahui.

2. Keterampilan (skill), merupakan kemampuan seseorang untuk melakukan suatu aktivitas atau pekerjaan. Telah dibahas di atas bahwa 
seseorang yang memiliki pengetahuan belum tentu memiliki kemampuan untuk melaksanakan pekerjaan. Keterampilan lebih sukar dimiliki daripada pengetahuan. Namun, seseorang yang memiliki keterampilan dengan sendirinya sudah memiliki pengetahuan atas pekerjaan yang mereka lakukan.

3. Konsep Diri (self-concept), merupakan sikap atau nilai individu. Nilai individu mempunyai sifat reaktif yang dapat memprediksi apa yang akan dilakukan oleh seseorang dalam waktu singkat. Konsep diri dipengaruhi oleh nilai-nilai yang dimiliki oleh seseorang yang diperolehnya sejak kecil sampai saat tertentu. Konsep diri menunjukkan bagaimana seseorang melihat dirinya sendiri atau sesuatu. Konsep diri ini mempengaruhi etika, cara pandang atau pengertian seseorang tentang sesuatu.

4. Ciri Diri (trait), adalah karakter bawaan diri, misalnya reaksi yang konsisten terhadap sesuatu. Seseorang yang mahir menerbangkan pesawat atau berprofesi sebagai pilot pesawat udara dapat dikatakan dia memiliki karakter bawaan diri sebagai pilot. Ciri diri ini merupakan karakteristik fisik, kognitif, dan social yang melekat secara permanen pada diri seseorang.

5. Motif (motive), adalah sesuatu yang dipikirkan atau diinginkan seseorang secara konsisten, yang dapat menghasilkan perbuatan. Kebutuhan, keinginan dan perhatian (concern) yang biasanya terjadi tanpa disadari ini akan mempengaruhi pemikiran seseorang untuk mencapai sasaran kerjanya sehingga pada akhirnya akan berdampak pada perilaku seseorang.

Seseorang untuk dapat memiliki kompetensi yang sesuai dengan pekerjaannya, maka harus memanfaatkan secara optimal kelima komponen utama kompetensi tersebut sehingga memiliki kompetensi yang sesuai dengan apa yang disyaratkan oleh pekerjaannya. Pegawai yang memiliki kompetensi yang mumpuni akan berpengaruh terhadap kinerjanya dalam organisasi. 
POLITICON : Jurnal Ilmu Politik Vol.1 No.1 ; Hal 88 - 103

Website : http://journal.uinsgd.ac.id/index.php/politicon

ISSN : 2685-6670 ( Online )

Prawirosentono (2010:2) menyatakan bahwa: Kinerja (performance) adalah hasil kerja yang dapat dicapai oleh seseorang atau kelompok orang dalam suatu organisasi sesuai wewenang dan tanggung jawab masing-masing dalam rangka upaya mencapai tujuan organisasi yang bersangkutan secara legal, tidak melanggar hukum, dan sesuai dengan moral ataupun etika.

Menurut Dharma (2004:355), dimensi untuk mengukur kinerja, adalah sebagai berikut:

1. Kuantitas kerja, yaitu jumlah yang harus diselesaikan atau dicapai.

2. Kualitas kerja, yaitu mutu yang dihasilkan (baik tidaknya).

3. Ketepatan waktu, yaitu sesuai tidaknya dengan waktu yang direncanakan.

Keterkaitan antara kompetensi dan kinerja seperti yang dikemukakan Moeheriono (2009:4) bahwa: "Kompetensi dapat menyebabkan atau digunakan untuk memprediksikan kinerja seseorang". Hal ini menggambarkan bahwa kompetensi pegawai berpengaruh terhadap kinerja pegawai. Keduanya merupakan unsur penting di dalam administrasi publik dan manajemen sumber daya manusia.

Berdasarkan uraian di atas maka disusun paradigma penelitian dalam kerangka pemikiran sebagai berikut:

\begin{tabular}{|c|c|}
\hline $\begin{array}{c}\text { Komponen Kompetensi Pegawai (X) } \\
\text { (Spencer dan Spencer dalam } \\
\text { Hutapea dan Thoha, 2008:28) }\end{array}$ & $\begin{array}{c}\text { Dimensi Kinerja Pegawai (Y) } \\
\text { (Dharma, 2004:355) }\end{array}$ \\
\hline $\begin{array}{ll}\text { 1. } & \text { Pengetahuan (knowledge) } \\
\text { 2. } & \text { Keterampilan (skill) } \\
\text { 3. } & \text { Konsep diri (self-concept) } \\
\text { 4. } & \text { Ciri diri (trait) } \\
\text { 5. } & \text { Motif (motive) }\end{array}$ & $\begin{array}{l}\text { 1. Kualitas kerja } \\
\text { 2. Kuantitas kerja } \\
\text { 3. Ketepatan waktu }\end{array}$ \\
\hline
\end{tabular}

Gambar 1. Paradigma Penelitian Pengaruh Kompetensi Terhadap Kinerja Pegawai Berdasarkan hasil pengujian secara simultan diketahui bahwa besarnya pengaruh dari variabel X ke Y adalah 0.604 yang merupakan kuadrat dari nilai koefisien korelasi ganda $(\mathrm{R}=0.777)$, sedangkan besarnya pengaruh variabel lain yang tidak diteliti adalah sebesar 0.396, untuk lebih jelasnya dapat dilihat pada gambar berikut ini: 


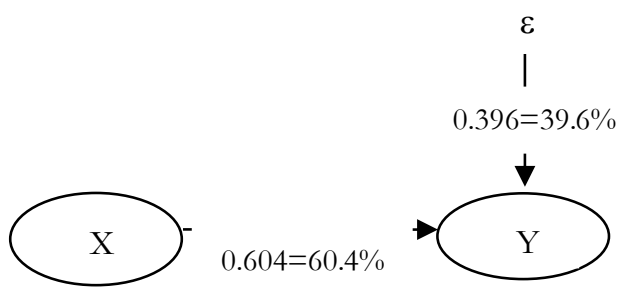

Gambar 2. Besarnya Pengaruh Variabel X ke Y

Berdasarkan hasil analisis uji kontribusi pengaruh, menunjukkan bahwa variabel kompetensi pegawai berpengaruh terhadap kinerja adalah sebesar 0.604 atau 60.4\%. Kompetensi pegawai yang terdiri dari komponen pengetahuan $\left(X_{1}\right)$, keterampilan $\left(X_{2}\right)$, konsep diri $\left(X_{3}\right)$, ciri diri $\left(X_{4}\right)$ dan komponen motif $\left(\mathrm{X}_{5}\right)$ berpengaruh cukup kuat terhadap kinerja yang terdiri dari aspek kualitas kerja, kuantitas kerja dan ketepatan waktu.

Kompetensi pegawai yang terdiri dari komponen pengetahuan $\left(\mathrm{X}_{1}\right)$, keterampilan $\left(\mathrm{X}_{2}\right)$, konsep diri $\left(\mathrm{X}_{3}\right)$, ciri diri $\left(\mathrm{X}_{4}\right)$ dan motif $\left(\mathrm{X}_{5}\right)$ berpengaruh sebesar $60.4 \%$ terhadap kinerja pegawai yang terdiri dari aspek kualitas kerja, kuantitas kerja dan ketepatan waktu, sedangkan selebihnya yaitu sebesar 39.6\% dipengaruhi oleh variabel lain yang tidak diteliti dalam penelitian ini.

Berdasarkan hasil pengujian secara parsial didapat nilai-nilai koefisien jalur sebagai berikut: besarnya pengaruh $\mathrm{X}_{1}$ ke $\mathrm{Y}$ adalah sebesar 0.063, pengaruh $\mathrm{X}_{2}$ ke $\mathrm{Y}$ adalah sebesar 0.124 , pengaruh $\mathrm{X}_{3}$ ke $\mathrm{Y}$ adalah sebesar 0.164, pengaruh $\mathrm{X}_{4}$ ke $\mathrm{Y}$ adalah sebesar 0.194 dan pengaruh $\mathrm{X}_{5}$ ke $\mathrm{Y}$ adalah sebesar 0.059, dengan besarnya pengaruh variabel lain adalah sebesar 0.396 , untuk lebih jelasnya besar pengaruh dapat dilihat pada gambar sebagai berikut: 


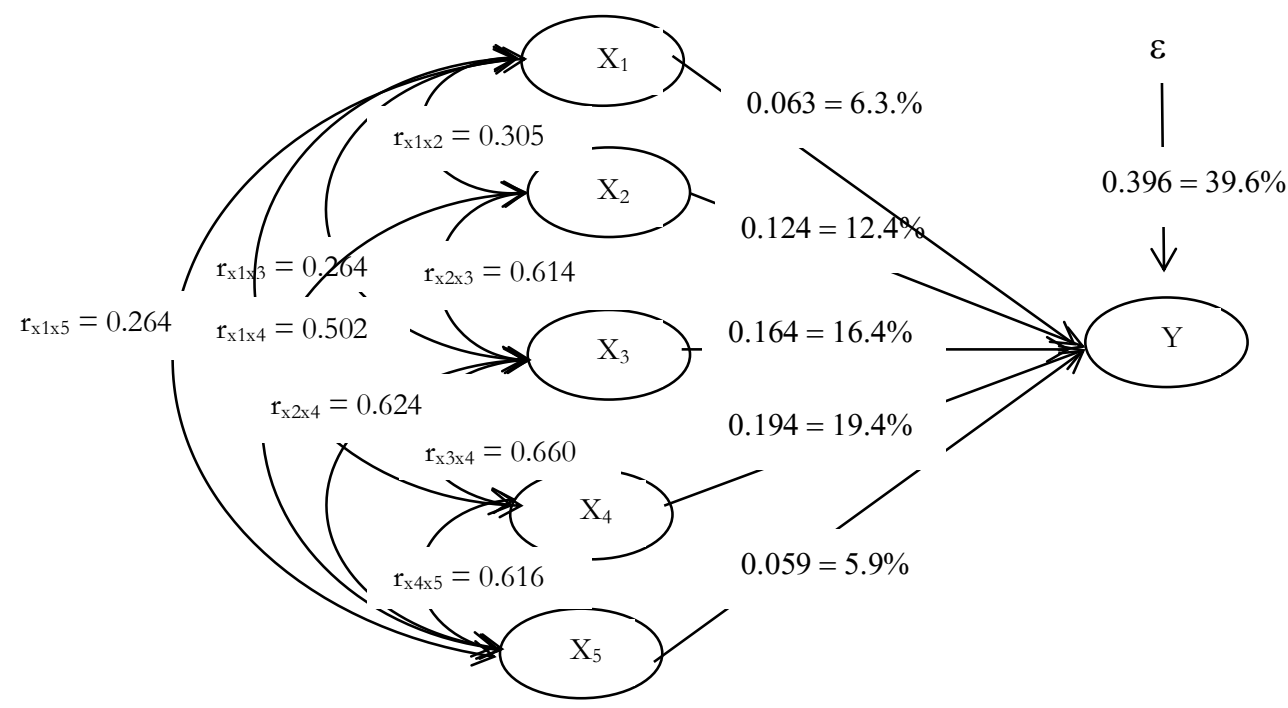

Gambar 3. Besarnya Pengaruh Dimensi $X_{1}, X_{2}, X_{3}, X_{4}$, dan $X_{5}$ ke $Y$

Hasil pengolahan data menunjukkan bahwa komponen pengetahuan yang dimiliki para pegawai berpengaruh terhadap kinerja adalah sebesar 0.063 atau $6.3 \%$. Komponen pengetahuan ini terdiri dari indikator mengetahui tugas pokok, mengetahui wawasan dan mengetahui standar kerja sedangkan kinerja diwakili oleh ketepatan kualitas, ketepatan kuantitas dan ketepatan waktu.

Hasil pengolahan data menunjukkan bahwa komponen keterampilan yang dimiliki para pegawai berpengaruh terhadap kinerja adalah sebesar 0.124 atau $12.4 \%$. Komponen keterampilan terdiri dari indikator memiliki keahlian fisik, mampu mengatasi masalah dan menguasai tugas pokok sedangkan kinerja diwakili oleh ketepatan kualitas, ketepatan kuantitas dan ketepatan waktu.

Hasil pengolahan data menunjukkan bahwa komponen konsep diri berpengaruh terhadap kinerja adalah sebesar 0.164 atau $16.4 \%$. Komponen konsep diri ini terdiri dari indikator mampu memprediksi masalah, memiliki pandangan dan bertanggungjawab kepada pekerjaan sedangkan kinerja diwakili oleh ketepatan kualitas, ketepatan kuantitas dan ketepatan waktu.

Hasil pengolahan data menunjukkan bahwa komponen ciri diri 
berpengaruh terhadap kinerja adalah sebesar 0.194 atau 19.4\%. Komponen ciri diri ini terdiri dari indikator kerjasama dalam kelompok, berani ambil resiko dan komitmen dalam tugas sedangkan kinerja diwakili oleh ketepatan kualitas, ketepatan kuantitas dan ketepatan waktu.

Hasil pengolahan data menunjukkan bahwa komponen motif berpengaruh terhadap kinerja adalah sebesar 0.059 atau 5.9\%. Komponen motif ini terdiri dari indikator lingkungan kerja nyaman, mempunyai kepekaan diri dan mampu mengembangkan diri sedangkan kinerja diwakili oleh ketepatan kualitas, ketepatan kuantitas dan ketepatan waktu.

Berdasarkan hasil analisis diperoleh adanya pengaruh variabel kompetensi pegawai yang terdiri dari komponen pengetahuan $\left(\mathrm{X}_{1}\right)$, keterampilan $\left(\mathrm{X}_{2}\right)$, konsep diri $\left(\mathrm{X}_{3}\right)$, ciri diri $\left(\mathrm{X}_{4}\right)$ dan komponen motif $\left(\mathrm{X}_{5}\right)$ terhadap kinerja (Y), yang berpengaruh sebesar 60.4\%. Sedangkan selebihnya yaitu sebesar 39.6\% dipengaruhi oleh variabel lain yang tidak diteliti dalam penelitian ini

\section{SIMPULAN}

Berdasarkan hasil penelitian tentang pengaruh kompetensi pegawai terhadap kinerja pegawai pada Biro Pemerintahan dan Kerjasama Sekretariat Daerah Provinsi Jawa Barat yang telah dibahas pada bab sebelumnya, maka kesimpulkan hasil penelitian ini adalah sebagai berikut:

1. Secara simultan, variabel kompetensi pegawai berpengaruh positif dan signifikan terhadap kinerja pegawai pada Biro Pemerintahan dan Kerjasama Sekretariat Daerah Provinsi Jawa Barat dengan kontribusi sebesar 60,4\%, sedangkan sisanya sebesar 39,6\% dipengaruhi oleh variabel lain yang tidak diteliti. Artinya, kompetensi pegawai dapat menentukan tercapainya kinerja pegawai pada Biro Pemerintahan dan Kerjasama Sekretariat Daerah Provinsi Jawa Barat.

2. Secara parsial, variabel kompetensi pegawai yang terdiri dari komponen pengetahuan (knowledge) berpengaruh positif dan signifikan terhadap kinerja pegawai sebesar 6,3\%, keterampilan (skill) 
berpengaruh positif dan signifikan terhadap kinerja pegawai sebesar 12,4\%, konsep diri (self-concept) berpengaruh positif dan signifikan terhadap kinerja pegawai sebesar 16,4\%, ciri diri (trait) berpengaruh positif dan signifikan terhadap kinerja pegawai sebesar 19,4\% dan komponen motif (motive) berpengaruh positif dan signifikan terhadap kinerja pegawai sebesar 5,9\%. Komponen ciri diri (trait) merupakan komponen yang terbesar mempengaruhi kinerja pegawai yaitu sebesar 19,4\%, artinya komponen yang paling menentukan terhadap peningkatan kinerja pegawai. Sedangkan komponen motif (motive) merupakan komponen yang paling kecil pengaruhnya terhadap kinerja pegawai pada Biro Pemerintahan dan Kerjasama Sekretariat Daerah Provinsi Jawa Barat dengan kontribusi sebsar 5,9\%, artinya komponen ini kurang menentukan tehadap peningkatan kinerja pegawai.

\section{DAFTAR PUSTAKA}

Abidin, Said Zainal. (2004). Kebijakan Publik. Jakarta: Salemba Humanika.

Affandi, Muchtar. (1982). Ilmu-Ilmu Kenegaraan. Bandung: Lembaga Penerbitan Fakultas Sosial Politik.

As'ad, Moh. (2004). Psikologi Industri. Jakarta: Liberty.

Dharma, Agus. (2004). Manajemen Supervisi. Jakarta: Raja Grafindo Persada.

Bouler, Nick et.al. (1999). People and Competences. London: Kogan Page.

Danim, Sudarwan. (2008). Kinerja Staf dan Organisasi. Bandung: Pustaka Setia.

Gibson, James L, dkk. (1996). Organizations (Organisasi dan Manajemen Perilaku-Struktur-Proses). Terjemahan Nunuk Adriani. Jakarta: Binaputra.

Guilford, J.P. (1956). Fundamental Statistic in Psychology and Education. New York: McGraw-Hill Book Company, Inc.

Hanafiah, Agus. (2012). Analisis Dampak Kompetensi Pegawai terhadap Kinerja Pegawai pada Bidang Pengembangan Karir Badan Kepegawaian Daerah Provinsi Jawa Barat. Bandung: Program Magister Ilmu Administrasi UNPAS Bandung. 
Hasan, Iqbal. (2002). Pokok-pokok Materi Metodologi Penelitian dan Aplikasinya. Bogor: Ghalia Indonesia.

Hutapea dan Thoha. (2008). Kompetensi Plus. Jakarta: Gramedia Pustaka Utama.

Iskandar. (2008). Manajemen Sumber Daya Manusia. Bandung: Multazam.

Islamy, M. Irfan. (2000). Prinsip-Prinsip Kebijaksanaan Negara, Jakarta: Bumi Aksara.

Mangkunegara, A.A Anwar Prabu. (2010). Manajemen Sumber Daya Manusia Perusahaan. Bandung: PT. Remaja Rosdakarya.

Mangkunegara, A.A Anwar Prabu. (2007). Manajemen Sumber Daya Manusia Perusahaan. Bandung: PT. Remaja Rosdakarya.

Mangkunegara, A.A Anwar Prabu. (2007). Evaluasi Kinerja SDM. Bandung: Refika Aditama.

Moeheriono. (2009). Pengukuran Kinerja Berbasis Kompetensi. Bogor: Ghalia Indonesia.

Muliawaty, Lia. (2013). Administrasi Publik Teori Kontemporer. Bandung: Remaja Rosdakarya.

Mulyasa. (2008). Standar Kompetensi dan Sertifikasi Guru. Bandung: Remaja Rosdakarya.

Nazir, Moh. (1999). Metode Penelitian. Jakarta: Ghalia Indonesia.

Ndraha, Taliziduhu, (2003), Budaya Pemerintahan dan Dampaknya Terhadap Pelayanan Masyarakat, Jakarta: Jurnal Ilmu Pemerintahan Edisi Ketiga Nigro, Felik A \& Nigro. (1999). Modern Public Administration. New York: Harper \& Raw Plubisher.

Nugroho, Riant. (2004). Kebijakan Publik untuk Negara-Negara Berkembang. Bandung: Bumi Aksara.

Nugroho, Riant. (2013). Change Management untuk Birokrasi. Jakarta: PT Elex Media Komputindo.

Puri, Indri Ratna. (2015). Analisis Pengaruh Kompetensi Pegawai Terhadap Efektivitas Kerja Pegawai pada Sekretariat Dinas Perindustrian dan 
POLITICON : Jurnal Ilmu Politik Vol.1 No.1; Hal 88 - 103

Website : http://journal.uinsgd.ac.id/index.php/politicon ISSN : 2685-6670 ( Online )

Perdagangan Provinsi Jawa Barat. Bandung: Program Magister Ilmu Administrasi UNPAS Bandung.

Robbin, Stephen P. (1994). Teori Organisasi, Struktur, Desain dan Aplikasi. Terjemahan Yusuf Udaya. Jakarta: Arcan.

Sedarmayanti. (2010). Sumber Daya Manusia dan Produktivitas Kerja. Bandung: Mizan.

Siagian, Sondang P. (1986). Manajemen Sumber Daya Manusia. Jakarta: Bumi Aksara.

Siagian, Sondang P. (1989). Filsafat Administrasi. Jakarta: Haji Masagung.

Singarimbun, Masri dan Sofian Effendi. (1982). Metode Penelitian Survai. Jakarta: LP3ES.

Sugiyono. (2009). Metode Penelitian Administrasi. Bandung: Alfabeta.

The Liang Gie. (1982). Ensiklopedia Administrasi. Jakarta: Gunung Agung. Wisesha, Ravi. (2014). Analisis Pengaruh Kompetensi Pegawai Terhadap Kinerja pada Cabang Pelayanan Dinas Pendapatan Daerah Provinsi Jawa Barat Wilayah Kota Bandung III Soekarno Hatta. Bandung: Program Magister Ilmu Administrasi UNPAS Bandung.

\section{Dokumen - Dokumen}

Peraturan Daerah Provinsi Jawa Barat Nomor 6 Tahun 2016 Tentang Pembentukan dan Susunan Perangkat Daerah Provinsi Jawa Barat.

Peraturan Gubernur Jawa Barat Nomor 45 tahun 2016 Tentang Kedudukan dan Susunan Organisasi Perangkat Daerah Provinsi Jawa Barat.

Undang-Undang Nomor 23 Tahun 2014 Tentang Pemerintahan Daerah 